\title{
Market Value of the Firm, Market Value of Equity, Return Rate on Capital and the Optimal Capital Structure
}

\author{
Chao Chiung Ting \\ Michigan State University, USA \\ E-mail: tingtch7ti@aol.com
}

Received: September 4, 2012

Accepted: September 19, 2012

Online Published: October 10, 2012

doi:10.5430/ijfr.v3n4p1

URL: http://dx.doi.org/10.5430/ijfr.v3n4p1

\begin{abstract}
The firm should pursue both maximum return rate on capital and maximum return rate on equity simultaneously. Maximum return rate on capital is the primary goal for firms because maximum return rate on capital guarantees efficiency. Therefore, maximum profit, maximum market value of the firm, maximum value of equity and maximum return rate on equity are inappropriate to be the primary goal. Since gross profit is independent of capital structure, capital structure just distributes return on capital into equity and debt (i.e., maximum return rate on equity determines capital structure). The maximum return rate on equity is the secondary goal that the firm pursues. Leverage makes the return rate on equity be higher than interest rate. Leverage explains the puzzle of equity premium.
\end{abstract}

Keywords: Maximum profit, Maximum value of the firm, Capital structure, Equity premium

\section{Introduction}

What is the primary goal for a business? There are many answers for this question. For examples, maximum profit, maximum market value of the firm, maximum market value of equity, maximum return rate on equity, optimal capital structure and ...etc. Microeconomics takes maximum profit as an axiom to allocate resource while finance applies value maximization to be a fundamental principle for business performance evaluation. It is no doubt that both microeconomics and finance intend to investigate the same object as firms. Why do they use different goals to study firms? The answer is: economists usually advocate new hypothesis (e.g., natural rate of unemployment) to solve economic puzzles and financial expert are accustomed to introduce new criteria to analyze business performance. They ignore the possibility that these "new things" may not be independent of "old things". For example, the price of a common stock depends on dividend, and therefore, stock price cannot be maximized if profit is not maximized. I generalize the idea behind this example to be following statements. If profit is not maximized, we can improve the circumstance that the firm has (i.e., we can increase value of the firm). Reversely, we can correct mistakes to increase profit if value is not maximized. Thus, resource allocation and value maximization are supposed to be two different approaches which should lead to the same conclusions. That is, we can unify microeconomics and finance. For example, Jensen [2001] tried to integrate resource allocation and value maximization by the enlighten value maximization theory.

Unfortunately, there is no paper to investigate the dependence between two different goals. By doing so, we omit an alternative approach to reconstruct firm theory for both microeconomics and finance. For the purpose of analysis, it is the first priority that we are necessary to ask following questions, which have never been asked by both economists and experts of finance. Are these goals equivalent or different? If these goals are different, which goal is prior to other goals? If these goals are different, is it possible that business fulfill these different goals simultaneously? Note that the most impressive argument made by Jensen [2001] I personally acknowledge is that the firm is impossible to maximize more than one goal.

Modigliani and Miller (MM) [1958] demonstrated that the maximum market value of the firm is irrelevant to its own capital structure. It implies that capital structure does not matter and the optimal capital structure does not exist. But we definitely assure that leverage affect profit and dividend. Further, we cannot help ask following questions. Should management authority pay no attention to capital structure? Does the optimal capital structure of the firm exist? Is the optimal capital structure a goal of business? Is capital structure just a tool to realize these goals? 
The objective of this paper is to answer these questions by a mathematic model based on optimal control theory and derived from comparison study about maximization. I am going to accomplish four arguments. (1) We measure the performance of the firm by return rate on capital (i.e., maximum return rate on capital is the primary goal of the firm). Maximum market value of the firm, maximum profit, maximum market value of equity and maximum return rate on equity are not the appropriate index to indicate performance of the firm. (2) The firm can maximize more than one goal. It denies Jensen's prediction. (3) The optimal capital structure is a tool to accomplish the goal that return rate on equity is maximized. Besides, the theory of minimum weighted average cost of capital (WACC) is rejected. (4) I deduce MM theorem from traditional firm theory (i.e., production-sale-cost-profit approach). It is wrong to interpret MM theorem as there is no optimal capital structure because MM theorem depends on gross profit and the optimal capital structure depends on net profit (i.e., gross profit minus interest payment). Moreover, the methodology of this paper is that the efficiency of resource allocation (i.e., production-sale-cost-profit approach) implies value maximization as well as value maximization requires efficiency of resource allocation.

Like the most financial analysis, MM and Jensen and Meckling [1976] did not involve production function, capital, labor, supply, demand and especially size of the firm. In the short run, both capital and equity are fixed. Maximum profit guarantees that the market value of the firm (gross profit is divided by market interest rate) and return rate on capital (gross profit is divided by capital) are maximized. Thus, these three goals are equivalent in the short run. In other words, resource allocation and value maximization are unified. Note that I will show that maximum profit does not guarantee maximum return rate on equity due to leverage in section 3.

In the long run, capital (i.e., size of the firm) and equity are flexible. Maximum profit, maximum market value of the firm and maximum return rate on equity becomes ambiguous in the long run because we do not know how much capital the firm should invest (i.e., we do not know the optimal size of the firm) yet. For example, a businessman can either invest 200 million with 20 million profit (return rate on capital $=10 \%$ and market value of the firm $=400$ million due to the assumption that market interest rate is 5\%) or invest 100 million with 15 million profit (return rate on capital $=15 \%$ and market value of the firm $=300$ million). From the view point of maximum profit and maximum market value of the firm, we should select the first plan. From the view point of efficiency, we should select the second plan because the second plan is more profitable and more efficient than the first plan. Consequently, maximum return rate on capital is the primary goal that the firm pursues in the long run. Maximum profit and maximum market value of the firm are rejected. I will demonstrate that maximum return rate on equity is a secondary goal for the firm in section 3.

Before I start to analyze capital structure, I must apply firm theory to determine the optimal quantity of capital that the firm requires for two reasons. First, the optimal quantity of capital means efficiency. Capital structure determines the composition of capital, not to determine the optimal quantity of capital. If the quantity of capital that we analyze is not optimal, the composition of capital is not optimal. Second, I will show latter that return on capital (i.e., gross profit), which will be divided into return on equity (i.e., net profit) and interest payment by leverage (i.e., capital structure), is independent of capital structure. Since maximum market value of equity and maximum return rate on equity depends on net profit and maximum return rate on capital depends on gross profit, they are different goals. Maximum return rate on capital is prior to maximum return rate on equity because net profit depends on gross profit (i.e., gross profit is distributed into net profit and interest payment by leverage while leverage makes return rate on equity be maximized given gross profit).

This paper is organized as below. In section 2, maximum return rate on capital is identified to be the primary goal of business in the long run instead of maximum profit and value maximization, and I show how to test the hypothesis of maximum return rate on capital. In section 3, the maximum return rate on equity is a secondary goal of business and I derive the optimal ratio of debt to equity (i.e., the optimal capital structure) from maximum return rate on equity. I remark conclusions in section 4.

\section{Maximum Profit, Maximum Market Value, and Maximum Return Rate on Capital}

In MM's paper (equation (3) in page 268), they provides two methods to count market value of the firm. One is that market value of the firm is equal to the ratio of gross profit to market interest rate when the firm is financed by common stocks totally.

$$
\frac{P Q-W L}{r}
$$

Let $\mathrm{P}, \mathrm{Q}, \mathrm{w}, \mathrm{L}$ and $\mathrm{r}$ be price of product, quantity of product, wage rate, labor and market interest rate. $\mathrm{Q}$ is production function, a function of capital and labor, $Q=f(K, L)$ where $\mathrm{K}$ is capital. Gross profit (i.e., return on 
capital) is equal to sales minus wage expenditure, $P Q-w L$.

The other is that market value of equity plus debt is equal to market value of the firm. In this case, the firm uses leverage. Equation (1) becomes

$$
\begin{gathered}
\frac{P Q-r B-w L}{r}+B=e+B \\
K=E+B
\end{gathered}
$$

Let B, E, and e be borrowing, equity and market value of equity. The first part of equation (2) is market value of equity because $P Q-r B-w L$ is the net profit, i.e., return on equity. Net profit depends on capital structure (i.e., how much the firm borrows) but gross profit does not. Equation (1) and equation (2) always have the same result due to the key point that gross profit is independent of capital structure. That is what MM proved: market value of the firm is independent of capital structure. Equation (1) and equation (2) generalize MM's proof. Since gross profit is independent of capital structure, the optimal capital structure cannot be the primary goal that the firm pursues.

The larger gross profit is, the higher market value of the firm is. Maximum profit implies maximum market value of the firm. The concept of maximum profit makes sense if capital is given. In terms of microeconomics, maximum profit is the ultimate goal of business in the short run. In the long run, capital is flexible so that the absolute amount of "maximum profit" varies as the quantity of capital changes. Let’s study several cases listed as below.

Case 1: the firm financed by 200 million common stocks has market value 400 million because market interest rate is $5 \%$ and gross profit is 20 million. Both return rate on equity and return rate on capital are $10 \%$.

Case 2: The firm is financed by 100 million common stocks. Gross profit 15 million. Market value of the firm is 300 million. Return rate on capital is $15 \%$. Return rate on equity is $15 \%$.

Case 3: The firm is financed by 100 million common stocks and 100 million borrowing while the gross profit is 20 million and net profit is 15 million. The market value of the firm is 400 million and the market value of equity is 300 million (i.e., 15 million is divided by $5 \%$ market interest rate). The return rate on equity is $15 \%$ (15 million is divided by 100 million). The return rate on capital is $10 \%$.

In case 1 and case 3, the size of the firm (i.e., the amount of capital) is fixed, 200 million. Consequently, market value of the firm and return rate on capital are also fixed because market value of the firm and return rate on capital are independent of capital structure. But market value of equity and return rate on equity depends on capital structure. I shall discuss it in next section.

Comparing case 2 with case 1 and case 3, how do businessmen select the appropriate size of the firm? From the view point of maximum market value of the firm, businessmen should select either case 1 or case 3 . From the view point of efficiency, businessmen should select the maximum return rate on capital, case 2. The maximum return rate on capital does not require that gross profit should be largest one under different sizes of the firm. Given capital, maximum return rate on capital guarantees that gross profit is maximized. Thus, maximum profit and maximum market value of the firm are replaced by maximum return rate on capital to be the primary goal of the firm in the long run. This conclusion coincides with Ting [2010] who used maximum return rate on capital to determine the optimum size of the firm.

$$
\operatorname{Max} \frac{P Q-w L}{K}
$$

How does the firm maximize return rate on capital? Ting [2010] provided two landmarks.

$$
\begin{gathered}
P Q=P \frac{\partial Q}{\partial K} K+P \frac{\partial Q}{\partial L} L=R K+w L \\
\frac{K}{L}=\frac{w}{R}
\end{gathered}
$$

Let $\mathrm{R}$ be return rate on capital. Equation (5) means that the firm should pay each input factor by its own marginal productivity. If the firm does not use marginal productivity to be the guide for input hiring, the firm does not maximize its own return rate on capital. Equation (6) requires that capital-labor ratio must be equal to the ratio of wage rate to return rate on capital. Equation (6) also implies that return on capital (RK) is equal to wage expenditure 
$(w L)$. It is the easiest method to test hypothesis of maximum return rate on capital that we compute the difference between return on capital and wage expenditure. If the difference is statistically significant, we conclude that the firm has room to improve return rate on capital and return rate on capital is supposed to be lower than average return rate on capital. If the difference is relatively little, return rate on capital should be above the average return rate on capital. Note that I assume there are efficient companies and inefficient companies in markets so that the return rate on capital of an efficient (inefficient) company is higher (lower) than average return rate on capital.

\section{Equity and Capital Structure}

Following MM's pioneering work, trade-off models (e.g., Kraus and Litzenbrger [1973]) and Pecking order models (e.g., Myers and Majluf [1984]) also neglected the optimal quantity of capital (i.e., firm theory). It leads financial analysis to apply maximum market value approach and WACC to study the optimal capital structure. WACC cannot determine the optimal quantity of capital that the firm requires because WACC only determine cost of capital, which is a part of firm theory in microeconomics. Suppose that the cost of equity is equal to the cost of debt. In this case, the optimal ratio of equity to debt (i.e., capital structure) is indeterminate according to minimum WACC.

By equation (2), market value of the firm is equal to market value of equity plus borrowing. Thus, market value of the firm is the upper limit of market value of equity. The maximum market value of equity is equal to market value of the firm. It implies that the firm is completely financed by common stock. In other words, maximum market value of equity and leverage are mutually exclusive.

Let's study one more case.

Case 4: The firm is financed by 50 million common stocks and 150 million borrowing while gross profit is 20 million. The market value of the firm is 400 million while market value of equity become 250 million (12.5 million is divided by $5 \%$ market interest rate). The return rate on equity is $25 \%$.

By case 1, case 3 and case 4, we acknowledge that (1) the higher return rate on equity, the higher stock price and (2) market value of equity may decrease when return rate on equity increase. Thus, maximum return rate on equity and maximum market value of equity are different ideas. From the view point of stock holders, they should prefer maximum return rate on equity to maximum market value of equity because stockholders pursue their own efficiency. Moreover, Jensen and Meckling [1976] argued that managers have an incentive to strive for maximization of equity price. Maximum return rate on equity eliminates interest conflict problem between stockholders and managers.

The interest rate that the firm pays for its borrowing may be different from market interest rate. For example, the ratio of debt to equity is so high that lenders have to charge extra risk premium. Besides, it is possible that the firm issues long term bond while market uses short term interest rate to count market value of the firm. We have following equations to determine the optimal capital structure.

$$
\begin{aligned}
& \operatorname{Max} \frac{P Q-w L-i\left(\frac{B}{E}\right) B}{E}=\frac{P Q-w L-i\left(\frac{B}{E}\right) B}{K-B} \\
& \frac{P Q-i B-w L}{r}+B=\frac{P Q-w L}{r}+\left(1-\frac{i}{r}\right) B
\end{aligned}
$$

Let $\mathrm{i}$ be the interest rate that the firm pays for borrowing. I assume that market interest rate, $\mathrm{r}$, is given exogenously. Equation (2') is modified from equation (2). The market value of the firm depends on capital structure in equation (2') because the higher i means the less return for equity and then the less market value of equity. It demonstrates that MM's conclusion is not universal true. The necessary condition for the maximum return rate on equity is

$$
\begin{gathered}
\left(P \frac{\partial Q}{\partial K} \frac{\partial K}{\partial B}-i-\frac{\partial i}{\partial B} B\right)(K-B)=0 \\
\frac{\partial i}{\partial B}=i^{\prime} \frac{\partial \frac{B}{K-B}}{\partial B}=i^{\prime} \frac{K-B}{(k-B)^{2}}=\frac{i^{\prime}}{K-B}
\end{gathered}
$$

Since $K=E+B, \frac{\partial K}{\partial B}=1$ and $\frac{\partial K}{\partial E}=1$. In equation (8), I exclude the case that the firm is financed by borrowing totally. Thus, we get

$$
P \frac{\partial Q}{\partial K}-i-i^{\prime} \frac{B}{K-B}=0
$$




$$
\frac{B}{E}=\frac{B}{K-B}=\frac{P \frac{\partial Q}{\partial K}-i}{i^{\prime}}
$$

Equation (11) gives us the optimal capital structure. It is crucial that firms are allowed to pursue maximum return rate on capital and maximum return rate on equity simultaneously. Notice that the optimal capital structure is the tool to accomplish the goal that return rate on equity should be maximized.

Ting [2010] used sales and cost to determine the maximum return rate on capital and then the optimal size of the firm. Thus, the argument that the firm should evolve to the point of the minimum long run average cost is rejected. Similarly, I use gross profit and interest (i.e., cost of capital) to determine the maximum return rate on equity and then the optimal capital structure. The minimum WACC is a partially analysis depending on cost only. The idea of the minimum WACC is the same as the argument of the minimum long run average cost. The minimum WACC is rejected in a general firm theory like this paper.

How to test the optimal capital structure? We count return rate on capital first. We identify the interest rate that the firm pays for borrowing next. We modify the ratio of debt to equity gradually in order to calculate the optimal ratio of debt to equity, given performance. By doing so, we can calculate the difference between the optimal ratio of debt to equity and the ratio of debt to equity that the firm actually has. If the difference is insignificant, it implies that managers apply leverage to enhance return rate on equity and managers pursue maximum return rate on equity. If the difference is significant, managers may not recognize the optimal capital structure well. It is the second test: we calculate the difference between return rate on capital (i.e., assets) and return rate on equity, If the difference is significant, managers apply leverage to enhance return rate on equity. Equation (11) implies the third test: the difference between return rate on capital and borrowing interest rate is larger, the leverage is higher.

There are strong evidences to support the negative relationship between leverage and returns, e.g., Nissim and Penman [2003], Dimitrov and Jain [2008], and George and Hwang [2009]. High leverage sometimes is the effect caused by bad business performance. In this case, high leverage is not the cause of high return rate on equity. For example, the firm borrows for short of cash flow when the firm faces deficit. Thus, performance of the firm and leverage of the firm have negative relationship. That high leverage is the effect of bad business performance is supported by Rajan and Zingales [1995], who found negative relation between return rate on assets and leverage. To summary, it is wrong to argue that high leverage leads to low returns rate on equity because gross profit (i.e., criteria to measure business performance) is independent of leverage.

\section{Conclusions}

It is clear now that we know how to make a financial plan for investment. First, we determine the optimal amount of capital, i.e., optimal size of the firm. When capital is given, maximum return rate on capital assures that gross profit is maximized and market value of the firm is maximized. Second, we use maximum return rate of equity to determine the optimal ratio of debt to equity. Notice that maximum return rate on capital is prior to maximum return rate on equity. Return rate on capital is independent of capital structure because capital structure cannot affect gross profit. To summary, investment plan pursues maximum return rate on capital and maximum return rate on equity simultaneously.

Equation (11) shows that return rate on capital (i.e., marginal productivity of capital, $P \frac{\partial Q}{\partial K}$ ) is greater than interest rate that the firm pays for borrowing. It means that return rate on equity is always higher than market interest rate. Mehra and Prescott [1985] found that real return to stock is six percent higher than Treasury bill. The equity premium, which is composed of dividend and changes in stock price, cannot be explained by risk aversion. The interest rate firms pay for borrowing is higher than the interest rate of Treasury bill. Since firms use leverage to make return rate on equity be higher than the interest rate of Treasury bill, leverage is able to explain equity premium systematically.

Finally, economics that focuses on efficiency of resources allocation and finance that concentrates on reward to equity are unified in this paper to replace the old firm theory.

\section{References}

Dimitrov, Valentein, \& Jain, Prem. (2008). The value Revelance of Changes in Financial Leverage beyond Growth in Assets and GAAP Earnings. Journal of Accounting, Auditing and Finance, 101-222. 
George, Thomas, \& Hwang, Chuan-Yang. (2009). A Resolution of the Distress Risk and Leverage Puzzles in the Cross-Section of Stock Returns. Journal of Financial Economics, 56-79.

Jansen, Michael. (2001). Value Maximisation, Stakeholder theory, and the Cooperate Objective Function. European Financial Management, 3, 297-317. http://dx.doi.org/10.1111/1468-036X.00158

Jansen, Michael, \& Meckling, William. (1976). Theory of the Firm: Managerial Behavior, Agency Costs and Owenership Structure. Journal of Financial Economics, 305-360. http://dx.doi.org/10.1016/0304-405X(76)90026-X

Kraus, Alan, \& Litzenberger, Robert. (1973). A State-Preference Model of Optimal Financial Leverage. Journal of Finance, 911-922. http://dx.doi.org/10.1111/j.1540-6261.1973.tb01415.x

Mehra, Rajnish, \& Prescott, Edward. (1985). The Equity Premium: A Puzzle. Journal of Monetary Economics, 145-161. http://dx.doi.org/10.1016/0304-3932(85)90061-3

Modigliani, Franco, \& Metron Miller. (1958). The Cost of Capital, Corporation Finance, and the Theory of Investment. American Economic Review, 261-297.

Myers, Stewart, \& majluf Nicolas. (1984). CorporateFinancing and Investment Decisions When Firms Have Information That Investors Do Not Have. Journal of Financial Economics, $187-221$. http://dx.doi.org/10.1016/0304-405X(84)90023-0

Nissim, Dornon, \& Penman, Stephen. (2003). Financial Statement Analysis of Leverage and How It Performs About Profitability and Price-to-Book Ratios. Review of Accounting Studies, 531-560. http://dx.doi.org/10.1023/A:1027324317663

Rajan, Raghuram, \& Zingales, Luigi. (1995). What Do We Know about Capital Structure: Some Evidence from International Data. Journal of Finance, 1421-1460. http://dx.doi.org/10.1111/j.1540-6261.1995.tb05184.x

Ting, Chao Chiung. (2010). The Optimal Size of the Firm and Growth Theory. European Journal of Economics, Finance and Administrative Science, 25-28. 